\title{
Criminal Law Protection of Human Life and Prevention of Murder in Uzbekistan (On the Example of Women)
}

\section{Khurshida Mirziyatovna Abzalova}

Doctor of Science in law, Associate professor of theDepartment of Criminal Law, Criminology and Fight against, Corruption of Tashkent State University of Law

+998909129586,lawyer_abzalova@mail.ru

\begin{abstract}
In the world, protection of the rights and interests of the individual is one of the priority areas for improving legislation. In this process, a special role is played by criminal legislation, which is designed to ensure the protection of human life as the most valuable object of criminal law protection. The fight against crimes against life, in particular murder, is the highest priority for judicial and law enforcement agencies. In this regard, the adoption of effective measures to counter deliberate killings, the study of the causes and conditions that contribute to their Commission, as well as the identity of the killer are of great scientific and practical importance. According to statistics provided in the UN Global Study on Homicide report for 2019, the number of murders per 100,000 people in El Salvador is 61.8, in Brazil-30.5, in Russia-10.82, in Switzerland-5.35, in Uzbekistan-3, Finland-1.42, in the UK-1.2[1]. All this indicates the need to pay special attention to effective criminal law protection of human life.
\end{abstract}

Keywords:criminal law protection, Murder, independent crime, criminal attacks, Criminal code.

Article Received: 10 August 2020, Revised: 25 October 2020, Accepted: 18 November 2020

\section{Introduction}

In the world, special attention is paid to research on improving criminal legislation, assigning a fair punishment for premeditated murder, protecting the life of the individual as an object of criminal law protection, establishing strict measures of responsibility and punishment for crimes of murder and other crimes against life, improving the effectiveness of measures to prevent premeditated murder, investigating the causes and conditions that contribute to the Commission of crimes against life, in particular murders, and criminological characteristics of the killer's personality, correct qualification of the specified crimes.

In our country, measures are being taken to improve criminal legislation, strengthen the judicial system, and protect the rights and legitimate interests of individuals. In the Strategy five priority directions of development of the Republic of Uzbekistan in the years 2017-2021 the "improvement and liberalization of criminal law and criminal procedure law, the decriminalization of certain criminal acts, humanization of criminal punishments and the order of their execution" was identified as a priority to ensure the rule of law and further reforming judicial-legal system, therefore the study of this sector is important. \section{murder}

The concept of public danger of

Murder is a deliberate, intentional attempt to deprive another person of life, or a conscious assumption of such a consequence of their actions if they want to achieve a different main goal or other criminal result, if this is not prevented or facilitated by the occurrence of the death of another person.

Murder is not only an attack on life, but also a deprivation of life, or an attack that led to death, causing the death of another person. Death is the final moment of 
human life.

The occurrence of the victim's death in the event of a violent attack on his life is an objective basis for criminal responsibility for the completed murder.

The death of a person in a violent attack on his life is a mandatory sign of murder as an independent type of criminal attacks on life. If an attempt on life is defined by the legislator as an independent crime, it cannot be characterized otherwise than as attempted murder.

Murder can be committed either by placing a person in a life-threatening state and leaving him in such a state with the intention of depriving him of life, or by leaving the victim in a helpless state, under the supervision or supervision of a person, or for whom he is otherwise obliged to take care, if the perpetrator not only foresaw the inevitability or possibility of his death, but also desired or deliberately allowed such a consequence.

\section{Main Part}

Murder can be committed with direct or indirect intent. If we are talking about an attempt, it always implies direct intent: the offender was going to commit a crime deliberately, but regardless of his actions, it did not take place. "Life" is defined as a special form of the existence of matter", expressed in this case in the "physiological existence of man". "In crimes against life, the perpetrator directly encroaches on a person's life."

A common point of view is that the beginning of a person's life is recognized as the beginning of physiological childbirth, the very process of birth. The latter position of scientists is reflected in article 98 of the criminal code of the Republic of Uzbekistan, where murder is recognized not only the deliberate deprivation of life of a newborn, but also of an unborn child during childbirth. Murder can be recognized as the deprivation of the life of an already living person, from the moment of birth as a result, not the process of childbirth, and until the end of his life as a result of death. In the end, it is not the viability of the child in the womb and during childbirth that should be the decisive argument in determining the moment of the beginning of a person's life, but the appearance and presence of a person as an object of encroachment, already born alive and still living.

Causing death to a person, depriving him of life determines the objective side of the murder, its main act (regardless of the methods of its Commission) and the moment of its end - the loss of life of the victim-a living person.

The objective side of murder is the socially dangerous and illegal deprivation of the life of another person. However, the typical degree of public danger of murder is special, extreme, and the illegality is criminally illegal, that is, provided for by the criminal law.

Murder can be committed either by action or inaction.

Murder can be committed through physical actions or mental effects on the victim when he dies guilty directly or with the aid of others, unaware of the actual nature of the acts committed in the prevailing situation or because of mental disability or infancy, or "hands" of the victim.

Homicide by omission occurs when the perpetrator intentionally fails to take care of the victim or perform actions that prevent the occurrence of death (for example, the mother stops feeding the child or the signalman does not warn the victim, who is in a dangerous area, about the beginning of explosive work). The perpetrator must have a real opportunity to perform the duties assigned to him.

If we consider the victims by gender, then we can see that in most violent crimes, the victims are men. This is due to several factors inherent only to the stronger sex: aggression and conflict. In view of such qualities, in many cases, men themselves are the organizers of conflicts. This indicator is lower, i.e. male victims of domestic crimes. Due to the fact that women are inferior to 
men in physical equipment[2].

Responsibility for murder by omission occurs only in cases where the perpetrator was aware of his duty and ability to perform actions, and also foresaw that the Commission of certain actions by him can prevent a fatal outcome in the situation that arose. If at least one of these elements is missing, there will be no criminal liability for the "result".

Jealousy as a motive for murder includes elements of distrust, anger, and selfishness. In most cases, it is a motive for murder in connection with a relationship between a man and a woman. There are a number of murders committed by a teenager on the grounds of jealousy due to the fact that parents or other relatives treated the victim (brother or sister) "better" than to him, i.e. to the person who committed this crime.

Most often, the reason for killing out of jealousy is an imaginary or actual "betrayal'.

Murder out of jealousy is often accompanied by a sense of revenge, when the reason for the murder is treason or unrequited love.

The Commission of murder is largely due to the extremely anti-social, anti-social attitudes of the person who commits it.

Recidivist murderers are characterized by a parasitic lifestyle. The percentage of people who do not have a permanent legal source of income among the identified killers ranges from $58-64 \%$.

There are three types of killer personalities in the literature:

The first type of killer is characterized by an aggressive and violent orientation, which has a deep-rooted, dominant, malicious character, which significantly loses its situational color. This is a consistently criminogenic type $(10-15 \%$ in the structure of murderers). They are characterized by militant egocentrism, bitterness, resentment, vindictiveness, increased aggression, refined cruelty, mental insensitivity, inability to empathize, cynicism.

A significant proportion of murderers (35-40\%) are focused on the use of violence. This orientation of the individual causes the Commission of a crime in combination with a conflict situation in which their emotional and moral promiscuity, unbalance and callousness are manifested. For a small reason or no reason, they are ready to use physical force and commit murder. These are habitual criminals.

The next type of killer is "intermediate" criminals, who are characterized by a partial criminal charge (20\%). Their focus on violence is not clearly expressed.

Murder for them often becomes a way to achieve particularly important goals for them, to seize some "good" in the name of which the life of another person is sacrificed. Murder in such cases is often facilitated by the drunk state of the killer.

\section{Responsibility for premeditated murder in the Republic of Uzbekistan}

At all times, premeditated murder was considered one of the most dangerous types of crimes. This is evidenced by the location of the article that provides for liability for this crime in the criminal code of the Republic of Uzbekistan. A special part of the criminal code of the Republic of Uzbekistan begins with the Chapter "Crimes against life" and article 97 "Premeditated murder", which indicates the high importance of this rule. According to statistics from the State statistics Committee of the Republic of Uzbekistan, 432 homicides were registered in the Republic of Uzbekistan in 2018, which is $17 \%$ lower than the same figure in 2017. Despite the decrease in this type of crime, the presence of cases of premeditated murder still causes concern on the part of the public and the state.

Currently, it is right to unite all efforts to preventTanosil diseases, all of which are closely relatedto each other. These include the following areas:the promotion of the 
prevalence of diseases, thesearch for economic factors and the analysis ofsocial conditions, etc., together increase theeffectiveness of the fight against sexuallytransmitted diseases[3].

September 22, 1994, was adopted the criminal code of the Republic of Uzbekistan[4]. (hereinafter - the criminal code of the Republic of Uzbekistan), which entered into force on 1 April 1995 In it, unlike the criminal code of the Uzbek Soviet Socialist Republic of 1959, a number of innovations, including the revision values of those or other public relations protected by criminal law.

In accordance with article 24 of the Constitution of the Republic of Uzbekistan, adopted on December 8, 1992, the right to life is an inalienable right of every person. At the same time, encroachment on a person's life is the gravest crime.

Based on the meaning of article 24 of the Constitution of the Republic of Uzbekistan, a special part of the criminal code of the Republic of Uzbekistan provides for premeditated murder as the "first" crime. This provision of the Constitution is also reflected in article 2 of the criminal code of the Republic of Uzbekistan, according to which the main task of the criminal law is to protect the individual, his rights and freedoms from criminal attacks. In this regard, the criminal code of the Republic of Uzbekistan contains a number of articles that establish responsibility for unlawful deprivation of life of another person-art. 97, 98, 99, 100, 101, 102 of Criminal code.

At present, bringing a person to the level ofsuicide is considered a socially dangerous crime, and he is criminally liable in the Criminal Codesof all the member states of the Commonwealth ofIndependent States. The first part of the SpecialPart of the Criminal Code of the Republic ofUzbekistan, entitled "Crimes against the person",consists of seven chapters (Chapter I - Crimesagainst life; Chapter II - Crimes against health;Chapter III - Crimes against life or health;Chapter IV - Against sexual freedom crimes;Chapter V - Crimes against the family, youth andmorals; Chapter VI Crimes against the freedom,honor and dignity of the individual; Chapter VII Crimes against the constitutional rights andfreedoms of citizens) [5].

It should be noted that the criminal code of the Republic of Uzbekistan provides for three types of murders:

- simple (part 1 of article 97);

- qualified, that is, committed under aggravating circumstances (part 2 of article 97);

- privileged, that is, committed under extenuating circumstances (article 98-101).

Of particular theoretical and practical importance is the study of the composition of premeditated murder. Traditionally, the theory of criminal law in the Republic of Uzbekistan considers the composition of the crime (as the basis of criminal responsibility) through the prism of four important elements:

- the object of the crime;

- the objective side of the crime;

- perpetrator;

- the subjective side of the crime.

The object of premeditated murder is a social relationship that develops over the implementation of a person's natural right, which is based on the principles of international and constitutional law, indicating the value of life. The implementation of these principles in a certain way ensures the safety of life. As in the United States, life as an object of crime cannot be evaluated either qualitatively or quantitatively. Indeed, criminal law protects a person's life without any discrimination (based on gender, race, religion, nation, citizenship, age, etc.). The criminal code of the Republic of Uzbekistan equally protects the life of every person, regardless of their state of health, the presence of illness, etc.It does not allow the deprivation of life and terminally ill person, even if they have their consent or request (euthanasia). However, most US States also do not allow euthanasia. 
However, under the laws of Oregon, California, Colorado, Vermont, Washington, new Jersey, the district of Columbia, and Hawaii, euthanasia is legally permitted. In turn, in these States, the actions of a person who takes medication for the purpose of taking life are not qualified as suicide and do not constitute premeditated murder.

\section{Results and Discussion}

The objective side of premeditated murder is expressed in the act (action or omission), the consequence of the occurrence of death and the causal relationship between them. As a rule, murder is committed by performing active physical actions that violate the integrity of the human body and lead to the onset of his death. A mandatory condition for liability for murder is the presence of a causal link between the action (inaction) of the perpetrator and the death of the victim.

The lawmaker in the Republic of Uzbekistan defines a natural sane person who has reached the age of responsibility as the subject of premeditated murder according to the following differentiated classification:

- 13 years (for premeditated murder under aggravating circumstances-two or more persons, with special cruelty, etc.);

- 14 years (simple premeditated murder without aggravating circumstances, premeditated murder in a state of strong emotional excitement);

- 16 years of age (intentional murder by the mother of a newborn child, intentional causing of death when exceeding the limits of the necessary defense, intentional causing of death when exceeding the necessary measures of detention of a person who committed a socially dangerous act, causing death by negligence, bringing to suicide, inducing suicide).

The subjective side of premeditated murder is expressed by direct intent, because the person committing the crime is aware of the public danger of the committed act, anticipates the consequences of the victim's death, and wants to deprive him of life.
As can be seen, legal analysis is the basis for classifying an act as murder in Uzbekistan. In turn, the criminal code of the Republic of Uzbekistan has a number of rules regarding premeditated murder:

- if there are aggravating circumstances, a long term of imprisonment and life imprisonment are provided for;

- do not apply the rules of sentencing when the active repentance of the perpetrator of the crime;

- for preparation of premeditated murder and attempt at it under aggravating circumstances, the rules of sentencing for an unfinished crime are not applied.

- if there are aggravating circumstances, a suspended sentence is not applied;

-in the presence of aggravating circumstances, conditional early release from punishment is not applied

- in the case of premeditated murder under aggravating circumstances, the punishment is not replaced with a milder one.

It should be noted that explanations of the Plenum of the Supreme Court (for example, resolution No. 13 of the Plenum of the Supreme Court of the Republic of Uzbekistan of 24 September 2004 "on judicial practice in cases of premeditated murder") are important for the qualification of murder according to article 21 of The law of the Republic of Uzbekistan of 14 December 2000 No.162-II "On courts" (in the new version), they are mandatory for courts, other bodies, enterprises, institutions, organizations and officials applying the legislation on which the explanation is given.

This resolution of the Plenum contains a number of explanations regarding the qualification of murders:

- an attempt on premeditated murder is possible only with direct intent;

as a simple homicide constitutes murder if there are no aggravating 
circumstances, aggravating and mitigating circumstances, as provided by the articles 98-101 of the criminal code of the Republic of Uzbekistan (for example, murder during a quarrel or fight in the absence of hooliganism, jealousy, by motives of revenge, jealousy, hostility, hatred, arisen on the basis of personal relationships, etc.);

- for distinguishing between premeditated murder and deliberate heavy injury, entailed death of the victim, you must consider the intent of the perpetrator, his subjective attitude to the outcome of their actions - the death of the victim;

- the methods of committing murder with special cruelty may include cases where before the deprivation of life or in the process of committing murder, the victim was tortured or suffered special suffering (the use of a painfully active poison, burning alive, prolonged deprivation of food, water, etc.).;

- actions of an official who committed premeditated murder when exceeding power or official powers should be qualified according to the totality of crimes provided for by articles of the Criminal code that establish responsibility for premeditated murder, and abuse of power and official powers, etc.

\section{Preventing murder as a violent crime}

Countering criminal encroachments should be considered one of the top national priorities of any country. The Republic of Uzbekistan is no exception. The strategy of action for further development of the Republic of Uzbekistan identifies the improvement of the system of crime prevention and prevention as one of the important tasks of the priority direction of ensuring the rule of law and further reform of the judicial and legal system.

In recent years, the issue of violence against women has become particularly relevant. The social significance of the problem of violent crime (murder) against women, on the one hand, and its lack of development in view of modern realities, on the other hand, determine the relevance of studying the criminological characteristics and issues of prevention of crimes against the life and health of women .

An extreme form of social and spiritual and moral ill-being in society has been the increase in the number of violent crimes, among which attacks on the life and health of women are not the least important. Section one of the criminal code of the Republic of Uzbekistan provides for criminal liability for violent crimes (murder). In turn, a number of articles in this section provide for aggravating circumstances in the form of committing a crime against a person who was financially or otherwise dependent on the perpetrator (especially women), as well as a woman who was known to be pregnant for the perpetrator, which indicates the position of the legislator with regard to violent crimes (murders) against women.

Judicial and investigative statistics show that women are far more likely to be victims of crimes in the area of criminal law relations than as perpetrators. Each year, they make up an average of $15 \%$ of the total number of people who have committed crimes, and $36 \%$ - among those recognized as victims of criminal attacks[6]. Unfortunately, 4 million women are victims of domestic violence every year, and 170,000 women are attacked during pregnancy, which is 5-9 months old. More than half of women in the United States who died as a result of homicide died at the hands of their former or current spouses[7]. This indicates that the criminal situation with violent attacks on the life and health of women is very unfavorable.

In July 1995, the Council of Europe held a pan-European seminar in Barcelona with the agenda "Resolving the relationship between the victim and the perpetrator: approaches, problems, and achievements in solving them". It noted that it encourages the creation of charitable organizations and public funds for the protection of victims of crime, which provide them with legal assistance, and a system of state 
compensation for damage caused.

The main idea of the concept was expressed in the introductory report as the restoration of justice.

Positive results of preventive work with criminals can lead to improvement of public morals in General, strengthening of socially significant relationships in many areas of life, especially in the family, they will also help to reduce crime among adolescents.

The protection of women's rights, in particular their lives and health, requires the state to take appropriate measures. In our view, the following measures should be taken to prevent violent crimes, including murders against women:

\section{Legal measure}

Protecting women's lives and health is important. This task also follows from the meaning of article 13 of the Constitution of the Republic of Uzbekistan, according to which human life and health is the highest value. The prevention of violent crime must be addressed in the context of the fight against crime in General. The model strategies and practical measures for the elimination of violence against women in the field of crime prevention and criminal justice provide that States are urged to periodically review, evaluate and revise their laws, codes and procedures, in particular their criminal legislation, in order to ensure that they are effective and effective in eliminating violence against women and eliminate provisions that provide for or justify violence against women[8].

The experience of foreign countries shows that legislative acts are the main tool for combating violent crimes. The U.S. violence against women act of 1991 authorized tougher penalties for rape and repeated attempts at rape. States were allocated funds to combat violence against women in areas where the situation was particularly difficult. In the 1980s, Canada adopted a program to stop family violence, which also included the creation of a Commission on violence against women.
In this regard, we consider it necessary to develop a Special program for the prevention of crime against women, which would include special techniques and methods to combat violent crime against women. This program should become a conceptual document in the field of prevention and prevention of crime against women, contain action programs aimed at minimizing the social consequences of violent crime and murder, as well as mechanisms for implementing these programs in order to provide medical, psychological, specialized psychiatric, psychotherapy and other types of assistance to persons affected by violent crimes.

\section{Social measure}

It is no secret that the prevention of any offense requires the adoption of public measures of influence. For increase of efficiency of fight against crime, including the prevention of violent crime, along with the study of the individual offender, the causes and conditions contributing to committing crimes, it is necessary a detailed study of the personality of the victim (victims of crime), and all of the circumstances in which the person has become such.

With all the need to improve family life and material well-being, special attention should be paid to intra-family relations. The absence or significant weakening of emotional contacts between parents and children, where the mother plays the leading role, gives rise to increased anxiety of people, their uncertainty in their social status and in themselves. Such situations are of criminal significance, since the Commission of crimes often serves as a means of overcoming anxiety.

The prevention of violent crimes, in particular murders against women, requires special attention. The solution to this problem has been of concern to the public since the end of the last century. In many Western countries (USA, Canada, UK, Germany, Italy) began public subsidies for crisis centres and shelters for women survivors of violence (such services are 
funded by the state budget and by voluntary donations).

Health professionals can play a more prominent role in early prevention of violence against women. They are able to identify and treat various health disorders caused by violence. Often, medical professionals have more opportunities to contact victims than law enforcement officers. In the 1990s, the American Medical Association issued guidelines to help train the medical corps in this regard. They talked about how to identify violence, how to discuss it with your patients, and how to refer patients to appropriate treatment. This practice could be useful in the Republic of Uzbekistan.

In particular, a Centre for analysis and synthesis of information on family violence in the Ministry of health and social protection (education and awareness-raising) was established in Canada. Crisis centers for women have been active in the Russian Federation since 1993. In 1999, the Association of crisis centers of the Russian Federation was officially registered, which today unites more than 35 centers in Russia. Crisis centers usually have helpline lines and organize consultations with psychologists and lawyers, while some have inpatient units for temporary accommodation of women victims. There is also a Center for women and the family that conducts various training seminars on violence against women.

Given the importance of social measures among other measures to prevent violent crime among women, public participation is important. Based on the experience of foreign countries, it is advisable to discuss the establishment of special institutions in the Republic that specialize in the social adaptation of women affected by various crimes, in particular violent crimes. The activities of these institutions will be aimed not only at the social adaptation of women, but also at Advisory, educational and educational work. Based on the specifics of these institutions, we believe it is appropriate to create them under the women's Committee of the
Republic of Uzbekistan, which will have a positive impact on the effectiveness of the institutions, and will also comply with the state policy on support for women.

\section{Organizational measure}

Investigation of violent crimes (including homicides) requires a high level of professionalism and prompt decisionmaking from law enforcement officials. Violent crimes against women are known to be latent. Because of this, interrogators and investigators often face problems overcoming the psychological barrier when talking to victims and injured women. Improving the activities of law enforcement agencies should go in two directions:

1. Specialization of law enforcement officers in the detection and suppression of violent crimes. It is practically useful to consider the issue of specialization of employees of investigative units of law enforcement agencies in solving violent crimes against women, which will also contribute to the quality of the preliminary investigation of crimes.

2. Development of forms and methods of their activity, their active participation in educational work. In our view, in order to provide high-quality professional training for investigative law enforcement officers, a special discipline should be included in the curriculum for training, retraining and professional development of employees, which includes training in special skills and abilities for the detection and investigation of violent crimes against women, and psychological training.

\section{Conclusion}

In conclusion, I would like to note that the prevention of violent crime will strengthen the rule of law and order in the Republic of Uzbekistan, increase the moral atmosphere in society and improve the education of the younger generation. For this purpose, it is advisable to implement a set of measures, including social, organizational and legal measures. It is important to develop a Special program for the prevention of crime against women, 
which would include special techniques and methods to combat violent crime against women.

\section{References}

[1] https://www.unodc.org/

[2]S.S.Niyozova. Prevention of Crime in the Family and the Role of Victimology in the Republic of Uzbekistan. International Journal of Advanced Science and Technology Vol. 29, No.3, (2020). p. 3962.

[3] A. A. Allanova. The Concept of Tanosil (Sexually TransmittedInfections) or HIV / AIDS Transmission and CriminalLiability Issues. International Journal of Pharmaceutical Research | Oct - Dec 2020 | Vol 12 | Issue 4. p. 4141.

[4]http://lex.uz.

[5]S.S.Niyozova. Reasons for Suicide and the Issue of Responsibility. International Journal of Pharmaceutical Research | Dec 2020 | Vol 12 | Supplementary Issue 3 p. 528.

[6] Musatova Ye. Ye. Criminological characteristics and prevention of violent crimes against the life and health of women. Abstract of the dissertation for the degree of candidate of legal Sciences. - R., 2011. - P. 7.

[7]http://www.owl.ru/win/books/easygender /part4_4.html

[8] Model strategies and practical measures for the elimination of violence against women in the field of crime prevention and criminal justice, adopted by General Assembly resolution 52/86 of 12 December 1997

[9] Abzalova, K. M. (2018). SOME MATTERS OF IMPOSITION OF PUNISHMENT FOR PREPARATION FOR PREMEDITATED MURDER IN THE CRIMINAL CODE OF THE REPUBLIC OF UZBEKISTAN. International Journal of Legal Studies (IJOLS), 4(2), 159-167.

$\begin{array}{llr}\text { [10] Абзалова, } & \text { X. } \\ \text { ОБЩЕСОЦИАЛЬНЫЕ } & \text { МЕРЫ } \\ \text { ПРЕДУПРЕЖДЕНИЯ ОПАСНОГО ДЛЯ } \\ \text { ЖИЗНИ }\end{array}$

НЕСОВЕРШЕННОЛЕТНИХ В СЕМЬЕ В УСЛОВИЯХ ПАНДЕМИИ. Review of law sciences, (2). 